\title{
INTERCULTURAL VARIATIONS IN PERSONAL SALES FACTORS IN THE CZECH AND U.S. AUTOMOTIVE MARKETS: PRACTICAL IMPLICATIONS FOR MARKETING
}

\section{Říha, D., Heinze, T., Stros, M.}

The purpose of this paper is to determine the intercultural and gender differences between American and Czech customers in relation to their perceptions of the verbal and nonverbal personality characteristics of a salesperson during the personal sales process. This research provides scholars and practitioners with an understanding of the cultural and gender-specific personal interaction factors that should be addressed when designing effective interpersonal sales approaches. The study utilized an experimental design approach. Personal selling scenarios were filmed and shown to respondents (university students acting as potential customers) who completed a survey regarding sales effectiveness. The resulting data was factor analyzed and a conceptual personal sales model was developed. The model suggests that salesperson authenticity and personal interaction factors impact sales success in both the U.S. and the Czech Republic. However, there are variations in the receptivity of potential U.S. and Czech customers to specific interpersonal communication factors. Gender-based variations were also identified. The study focused on automotive retail sales scenarios in the United States; however, the results can be generalized to similar markets.

Keywords: personal sales; personality of sales representative; intercultural differences; gender JEL classification: M1, M16, M3, M31

\section{Introduction}

Interpersonal communication and personality factors have historically been underrepresented in sales process training. Erevelles and Fukawa (2013) suggested that "more research that examines the effect of salesperson personality on affect in sales contexts is needed" (p18). The personal interactions that occur between a salesperson and a customer form an important variable that affects sales contexts and influences selling effectiveness (see also Busha et al., 2002; Sheth \& Sisodia, 2002). The current study's objectives are a) to expand the general understanding of the interpersonal factors that influence interactions and perceptions in sales situations, and b) to determine potential intercultural and gender differences in the perception of these interpersonal factors. The study specifically compares the U.S. and the Czech Republic. Despite rising globalism, Central European cultures remain markedly different from Western Europe and the U.S. (Kolman et al., 2003), and sales trainers/managers must understand the impact that cultural differences may have on personnel selection and process training.

The current study specifically reviews personal interaction factors and the manner in which these factors influence perceptions of salesperson authenticity in the U.S. and the Czech Republic. Kernis (2003, p. 13) defined authenticity as "the unobstructed operation of one's true, or core, self in one's daily enterprise". Perceptions of authenticity can partially mediate the relative utility and success of personal interactions. For example, prior research has demonstrated the positive influence of authentic leadership on staff and corporate success (Algera \& Lips-Wiersma, 2012; Avolio \& Gardner, 2005; Avolio 
et al., 2004; Diddams \& Chang, 2012; Neider \& Schriesheim, 2011; Rego et al., 2011; Tate, 2009; Walumbwa et al., 2010). However, interpersonal authenticity has not been extensively studied in sales scenarios. Therefore, the current research examines authenticity as an important factor in interpersonal sales situations.

The paper begins by reviewing extant literature regarding culture and authenticity. The study's conceptual framework is then presented and is followed by a factor analysis and results. The study's core experimental design was influenced by Plouffe et al.'s (2008) call for increased utilization of experimental designs, based on extant consumer behaviour theory, in sales research. The study's internationally tested sales model is built upon Solomon's ABC hierarchy (affect, behaviour, cognition) of attitude formation, the communication perception work of Mehrabian (1972), and Petty and Cacioppo's (1986) elaboration likelihood model.

\section{Literature Review}

The current section begins by providing a general overview of culture and a specific review of the divergent U.S. and Czech Republic cultural orientations. The review concludes by discussing authenticity and its place within the personal selling process.

\subsection{Culture}

Culture is the collective programming of the mind that distinguishes the members of one group or category from others (Hofstede, 2011). Personal interactions and communications can vary dramatically across cultures, and Hall (1976) highlighted these differences by dividing cultures into high-context (much of the information is implicit) and low-context (nearly everything is explicit) cultures. Sociologists Parsons and Shils (1951) offered a more nuanced description, suggesting that all human interactions are governed by the following five cultural choice pattern variables:

- Affectivity (need gratification) versus affective neutrality (restraint of impulses);

- Self-orientation versus collectivistic-orientation;

- Universalism (applying general standards) versus particularism (taking particular relationships into account);

- Ascription (judging others by who they are) versus achievement (judging them by what they do);

- $\quad$ Specificity (limiting relationships with others to specific spheres) versus diffuseness (no prior limitations on the nature of relationships).

Therefore, it can be seen that culture both involves and governs individual and group perceptions. Culture provides the fundamental foundation from which to judge and regulate one's own personal behaviours and the behaviours of others (Bedrnová \& Nový, 2007). Regarding communication, culture influences how and with whom we communicate, and the interpretations assigned to communication behaviours, the language through which we communicate, the utilization of non-verbal expressions, and the meanings assigned to these expressions (cf. Samovar \& Porter, 2003, p. 179; Gudykunst, 2004, p. 6). 
The differences in verbal and non-verbal cultural communication between the U.S. and the Czech Republic may be partially informed by variant cultures and historical developments. Many researchers (see Hall \& Hall, 1990; Hampden-Turner \& Trompenaars, 1990; Nový \& Schroll-Machl, 2003; Nový \& Schroll-Machl, 2005; Ort et al., 2002; Stewart \& Benett, 1991) have suggested that U.S. culture has been heavily influenced by the country's immigration history. The U.S. has absorbed numerous waves of immigrants seeking religious freedom and economic opportunity. The process of emigrating can be understood as secession from one's past and origins; the emigrant often finds himself / herself defying past authority and oppression in pursuit of the new country's cultural characteristics. In the U.S., these cultural characteristics have traditionally included the concepts of equality and individualism, which were often in direct contradistinction to the cultural characteristics of many Eastern European countries. After arriving in the U.S., the emigrant was frequently required to make immediate decisions (orientation on acting) in order to survive. A desire to improve living standards quickly followed the pursuit of survival, and thus work (performance orientation) became a culturally dominant orientation used to improve living standards. The country's performance orientation and work ethic was also informed by virtually unlimited natural resources. Moreover, a culturally individualistic bent was strengthened, as each family could rely on natural resources (and the personal work to harvest these resources) rather than societal or familial relationships to improve living standards. The pursuit of natural resources and a reduced need for familial or societal support resulted in a culture that was and still is characterized by great mobility, an alien concept within Czech culture.

Czech cultural standards differ from U.S. standards but have also been influenced by historical development. Throughout much of modern history, the Czech people have been part of large, non-Czech state entities. Their long-standing battles for independence have led to alienation from government structures (negative attitudes towards structures and institutions). Structures are considered positive only if they can be specifically used to facilitate personal or career goals; otherwise, Czechs often attempt to circumvent established structures (love of improvisation). The past socialist political environment furthered this need for improvisation. Although Czechs never internally identified with socialistic principles, the governing totalitarian regimes dictated an external conformity which resulted in an orientation towards personal communication that heavily utilized caution and indirectness in interactions (strong communication context). The exigencies associated with life under a totalitarian regime also bred conflict avoidance and fluctuating levels of confidence. To survive, Czechs relied heavily on their immediate social circles and thereby developed non-individualistic tendencies (people orientation).

\subsection{Authenticity}

Personal authenticity and the relative ease or discomfort ("uneasiness") towards perceptions of authenticity and gender are major factors that centrally influence human interactions. Much of today's selling is centered on personal interactions. Therefore, understanding the manner in which these interactions inform perceptions of authenticity can provide insights for the development of effective interpersonal sales techniques. Freud (1938) suggested that personal authenticity is derived from the inner equilibrium that exists in a proper balance among 1) physical [body language, "acting," (behavioural)], 2) 
emotional [joy, "feeling," (affect)], and 3) rational [mind, "thinking," (cognition)] characteristics. Balanced, authentic individuals facilitate a personal equilibrium in others and can thereby generate positive performance results (Algera \& Lips-Wiersma, 2012; Avolio \& Gardner, 2005; Avolio et al., 2004; Diddams \& Chang, 2012; Neider \& Schriesheim, 2011; Rego et al., 2011; Tate, 2009; Walumbwa et al., 2010). Although authenticity has been shown to yield positive performance results in many areas, the sales-specific effects of authenticity have not been closely examined.

To examine these sales-specific effects of authenticity, authenticity itself must be operationalized. Bauer (2002) suggested that interpersonal interactions and resulting perceptions of authenticity are built on how one participant senses that the other feels. These "feeling" perceptions are specifically governed by the analysis of 1) vocal tone; 2) body language; and 3) words (Mehrabian, 1972). For example, Damásio et al. (1996) suggested that physical gestures, mannerisms, and verbal content all contribute to the interplay between the body and consciousness. The current research therefore reviews three categories of personal interaction factors [related to vocal tone (emotional), body language (physical), and words (rational)] in order to determine the factors and cross-cultural variations that influence perceptions of authenticity in personal selling situations.

The model investigated here is constructed upon the established process by which consumers form attitudes and develop impressions of authenticity. The model corresponds to Solomon's (2003) ABC hierarchy of consumer behaviour, and builds on Mehrabian's (1972) communication perception work and Petty and Cacioppo's (1986) elaboration likelihood model of persuasion (ELM). The model suggests that congruent message levels from a salesperson (affect, behaviour, cognition) yield a positive influence on the customer's perception of salesperson authenticity. Fundamentally, the model suggests that a salesperson who balances feeling, action, and thinking will receive more favourable overall judgments. Conversely, an unbalanced approach will induce negative overall judgments (see also Bauer, 2002). In summary, the model suggests that the development of authentic perceptions in personal sales situations is governed by emotions (affect), body language (behaviour), and spoken content (cognition). The current research seeks to determine whether these key personal interaction factors vary by culture and by gender. To examine potential U.S./Czech cultural and gender differences, the current research evaluated the authenticity factor model illustrated in Figure 1. The model shows the three elements [emotional expressions (affect), body language (behaviour) and spoken word (cognition)] that influence perceptions of salesperson authenticity.

Figure 1 | Authenticity Factor Model

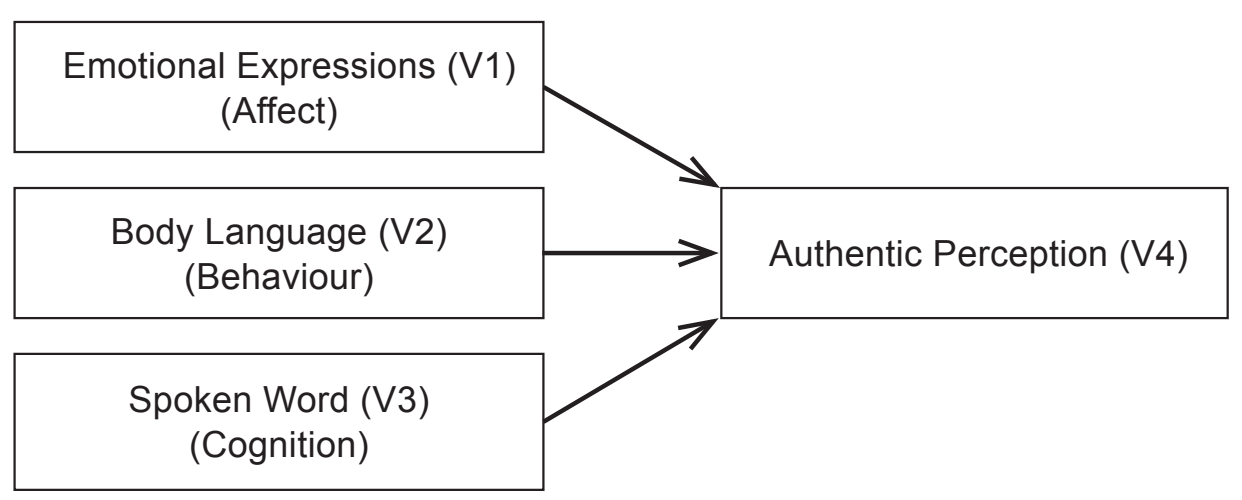




\section{Methods and Experimental Design}

\subsection{Scales}

To measure emotional expressions (affect), the current study utilized Havlena and Holbrook's (1986) emotional expression scale. Their scale includes 1) pleasure, 2) arousal and 3) dominance. The value of these items is determined by the 12-word pairs shown in Table 1.

Table 1 | Definitions and Measuring Items of Emotional Expression Variables

\begin{tabular}{|c|c|c|c|}
\hline Variable & Item & Sub-Item & Description \\
\hline \multicolumn{4}{|c|}{ Independent Variable } \\
\hline \multirow{12}{*}{$\begin{array}{l}\text { Emotional } \\
\text { Expressions (V1) } \\
\text { (Affect) } \\
\text { (Havlena \& } \\
\text { Holbrook, 1986) }\end{array}$} & \multirow{4}{*}{ Pleasure (V1.1) } & Happy - Unhappy & \multirow{12}{*}{$\begin{array}{l}\text { Each pair of words describes } \\
\text { a feeling dimension. Some of the } \\
\text { pairs might seem unusual, but you } \\
\text { may generally feel more one way } \\
\text { than the other. }\end{array}$} \\
\hline & & Pleased - Annoyed & \\
\hline & & Satisfied-Unsatisfied & \\
\hline & & Contented-Melancholic & \\
\hline & \multirow{4}{*}{ Arousal (V1.2) } & Stimulated - Relaxed & \\
\hline & & Excited - Calm & \\
\hline & & Frenzied - Sluggish & \\
\hline & & Agitated - Even-keeled & \\
\hline & \multirow{4}{*}{$\begin{array}{l}\text { Dominance } \\
\text { (V1.3) }\end{array}$} & Controlling - Controlled & \\
\hline & & Influential - Influenced & \\
\hline & & Dominant - Submissive & \\
\hline & & Autonomous - Guided & \\
\hline
\end{tabular}

Although communication scales have been developed (see Wiemann, 1977), these scales are not well suited to sales dialogue scenarios. Additionally, the evaluation of spoken content in sales scenarios is not specifically covered in the literature. Consequently, a new scale was developed for the current study (see Table 2).

Wood et al. (2008) and Barret-Lennard (1998) have described the manner in which individuals perceive others as authentic. Their conceptual model of authenticity is primarily driven by (1) authentic living; (2) acceptance of external influence; and (3) self-alienation. Wood developed a set of 12 Likert scale questions. To minimize the total number of questions, the current study reduced Wood's scale to eight questions that cover all the relevant items (see Table 3). 
Table 2 | Definitions and Measuring Items of Spoken Word Variables

\begin{tabular}{|l|l|l|}
\hline \multicolumn{1}{|c|}{ Variable } & \multicolumn{1}{|c|}{ Item } & \multicolumn{1}{c|}{ Sub-Item } \\
\hline \multicolumn{2}{|c|}{ Independent Variable } \\
\hline \multirow{4}{*}{$\begin{array}{l}\text { Spoken Word } \\
\text { (V3) } \\
\text { (Cognition) } \\
\text { (new scale) }\end{array}$} & $\begin{array}{l}\text { Content of } \\
\text { Speech (V3.1) }\end{array}$ & $\begin{array}{l}\text { Evaluate the content of the speech. } \\
\text { Was the content clear and well-articulated? }\end{array}$ \\
\cline { 2 - 3 } & $\begin{array}{l}\text { Organization of } \\
\text { Speech (V3.2) }\end{array}$ & $\begin{array}{l}\text { In order to make the content of a speech clear and easy to digest, it } \\
\text { needs to be well-organized. } \\
\text { a) Was the supporting argument logically structured? } \\
\text { b) Do the speaker's points flow logically from one to the next? }\end{array}$ \\
\cline { 2 - 3 } & $\begin{array}{l}\text { Content and } \\
\text { Style (V3.3) }\end{array}$ & $\begin{array}{l}\text { Does the content and style of the speech refer to what is spoken? } \\
\text { a) Did the style of the speech work for the content, or against it? } \\
\text { b) How convincing was the speaker? }\end{array}$ \\
\cline { 2 - 3 } & $\begin{array}{l}\text { Tone of Speech } \\
\text { (V3.4) }\end{array}$ & $\begin{array}{l}\text { The tone of the speech relates to the overall impact of the content } \\
\text { and the style. }\end{array}$ \\
\hline
\end{tabular}

Table 3 | Definitions and Measuring Items of Authentic Perception Variables

\begin{tabular}{|c|c|c|}
\hline Variable & Item & Sub-Item \\
\hline \multicolumn{3}{|c|}{ Dependent Variable } \\
\hline \multirow{8}{*}{$\begin{array}{l}\text { Authentic } \\
\text { Perception (V4) } \\
\text { (scale adapted } \\
\text { from Wood, } 2008 \\
\text { and Barret- } \\
\text { Lennard, 1998) }\end{array}$} & \multirow{4}{*}{$\begin{array}{l}\text { Authentic Living } \\
\text { (V4.1) }\end{array}$} & $\mathrm{He} / \mathrm{She}$ is aiming to be himself rather than to be popular. \\
\hline & & $\mathrm{He} / \mathrm{She}$ is true to himself. \\
\hline & & $\begin{array}{l}\text { He/She communicates according to his values and } \\
\text { beliefs. }\end{array}$ \\
\hline & & He/She communicates authentically. \\
\hline & \multirow{2}{*}{$\begin{array}{l}\text { Accepting External } \\
\text { Influence (V4.2) }\end{array}$} & He/She is giving his own opinion. \\
\hline & & He/She is not influenced by others. \\
\hline & $\begin{array}{l}\text { Self Authentication } \\
\text { (V4.3) }\end{array}$ & He/She has a high level of self-esteem. \\
\hline & Self Alienation (V4.4) & He/She feels alienated from himself. \\
\hline
\end{tabular}

\subsection{Experiment}

The current study used filmed sales scenarios that were shown to U.S. and Czech university students. It should be clarified that the students were viable participants; they are potential automotive customers and will at some point find themselves in a similar sales situation in which they must make a purchase decision that will be influenced by the salesperson. The filmed sales interactions involved the purchase of a car; the cars were familiar to the studied population (U.S. and Czech university students), and the buying situations offered both B-to-C and B-to-B applications. The car was a used hybrid model that carried a price premium. The sales situation involved an explanation of the overall lifetime value of the 
vehicle (along with supporting features, advantages, and benefits). Two professional actors (male and female) were employed in the video. A small group of experts was used to validate the research procedure and measurement scales, and to pre-test the questionnaires.

Four two-minute videos were produced. In each video, the independent variables (emotional expressions, body language, and spoken words) were highlighted according to the scheme illustrated in Table 4. For emotional expression (affect), the actors emphasized either high or low levels of pleasure, arousal, and dominance. For body language (behaviour), actors portrayed either high or low levels of immediacy cues, relaxation, movements and facial expressions. In relation to the spoken word (cognition), both positive and negative versions of the sales dialogue were scripted and acted. Each video featured a "salesperson" talking to a "customer." The videos were filmed so that the viewer could see the upper body of the salesperson but not the customer's facial expressions. Each video contained the following narrative sequence:

- Welcome and introduction;

- Product presentation pitch and application information;

- Final phase and pre-close attempt;

Prior to filming, each script was reviewed by subject matter experts. The videos were filmed at an automotive dealership in the U.S., and a standard video camera and microphone were used for the recordings.

Table 4 | Video Scheme

\begin{tabular}{|l|c|c|c|c|}
\hline Video & Gender & $\begin{array}{c}\text { Emotional Expressions } \\
\text { (Affect) }\end{array}$ & $\begin{array}{c}\text { Body Language } \\
\text { (Behaviour) }\end{array}$ & $\begin{array}{c}\text { Spoken Word } \\
\text { (Cognition) } \\
\text { (Sales Dialogue) }\end{array}$ \\
\hline $\mathbf{1}$ & Male & Positive & Positive & Positive \\
\hline $\mathbf{2}$ & Male & Negative & Negative & Negative \\
\hline $\mathbf{3}$ & Female & Positive & Positive & Positive \\
\hline $\mathbf{4}$ & Female & Negative & Negative & Negative \\
\hline
\end{tabular}

The videos were shown, using a randomized design, to 921 business students at public universities in the United States (443 students) and the Czech Republic (478 students). The survey took place at the start of a business lecture at each of the two participating universities: in the Czech Republic in January 2015 (University of Economics, Prague) and in the U.S. in December 2014 (California State University, Chico). Data collection was conducted by the authors of the present article. Participants were informed that participation was voluntary and confidential. The first page of the questionnaire contained a consent form. To eliminate response bias, participants were not informed of the purpose or set-up of the study. After the videos were shown, a 26-item questionnaire was administered. Viewers rated all 26 items on a Likert scale with " 1 " indicating "strongly disagree" and " 8 " indicating "strongly agree". Respondents were instructed to answer the questions quickly and spontaneously. The completed questionnaires were collected by study supervisors. 


\subsection{Video Content Analysis}

Data for the body language (behaviour) variable was collected via observational coding of each video. Body language was coded with fOCUS II software. fOCUS II is a multimedia application developed by the Open University and the BBC for use in coding observed behaviour in the field of psychology. The current study utilized event-based sampling, which permits a researcher to study the frequency, duration, latency, and intensity of the behaviour under study (Pellegrini, 2004; Bowker et al., 2009). This methodology has been successfully used in previous research (Bethell et al., 2007; Nock \& Kurtz, 2005). Physical description are believed to be the most 'objective' coding category (Pellegrini, 2004, p. 108).

The scoring of observational data is "similar to the scoring of any quantitative data within the social and behavioural sciences" (Bakeman, 2000, p. 293). In practical terms, a score is assigned for each construct. Scores are then summed across the overall observed session (Ostrov \& Keating, 2004). In the event of different session lengths, average rates of behaviour per session are generated (Crick et al., 2006). The current study's trained coders utilized these principles and standards to analyse the videos.

There are limitations associated with observational coding; however, Bakeman (2000, p. 293) has stated that "occasionally an error is made in the original coding, but as long as these problems are not systematic, this is not of concern". For the current study, the reliability between observers was assessed by calculating the percentage of agreement, giving a strong average rate of agreement of $91.9 \%$.

\section{Data Analysis}

\subsection{Exploratory Factor Analysis Rationale}

The current study used exploratory factor analysis to review the studied U.S. and Czech populations. Factor analysis is a multivariate statistical method which is utilized in applied research and is based on the following three concepts: data reduction, instrument development, and trait identification. There are two types of factor analysis: exploratory (EFA) and confirmatory factor analysis (CFA) (Jöreskog, 1969). In broad terms, EFA is heuristic; it involves the orderly simplification of interrelated measures and has traditionally been used to explore the possible underlying factor structures of a set of observed variables without imposing a preconceived structure on the outcome (Child, 1990). In EFA, the researcher has no expectations regarding the number or nature of the variables (Pett et al., 2003; Henson \& Roberts, 2006; Thompson \& Daniel, 1996; Swisher et al., 2004). Conversely, researchers use CFA to test a proposed theory or model; CFA is a form of structural equation modelling. CFA utilizes a priori assumptions and expectations regarding the number of factors and the factor theories or models that would provide the best fit.

The current study utilized EFA, since the researchers had no a priori constraints on the number or nature of factors that were to be identified. According to Huck (2012), a researcher performing an EFA usually only knows specific information such as the instruments used to measure each study variable, the nature of the research participants, related research findings, and theory-based hypotheses. The current study used ETA to accomplish the following: 
1) Determine the number of factors underlying a set of items (variables);

2) Provide a means of explaining variation among items (variables) using only a few newly created latent variables/factors, (e.g., condensing information);

3) Define the content or meaning of the variables/factors.

According to Meloun and Militký (2006), the process of EFA includes the following five steps. First, descriptive statistics are used to help ensure that variables have been correctly selected. Both the position and dispersion of the data are reviewed (averages, standard deviation, and communality). Communality is an important characteristic which shows how well the variable under consideration is predicted by the selected factors. Second, a correlation matrix is calculated to assess the total correlation of the data. Bartlett's sphericity test is used to assess whether factor analysis can be utilized; if the total correlation is more than 0.30 , factor analysis can be utilized. The third step involves using eigenvalues or cumulative percentages to select the factors. Next, a factor weight is calculated for each factor, and finally, factor scores are used to determine each factor and describe the results.

\subsection{Factor Analysis}

Prior to carrying out the factor analysis, the researchers confirmed that the sample was sufficiently large (Hair et al, 1995; Tabachnick \& Fidell, 2007) and verified the distribution normality of the collected data (Fabrigar et al., 1999). Additionally, a correlation matrix of the data was inspected for correlation coefficients over 0.30 (Tabachnick \& Fidell, 2007). Based on this review, several variables were excluded from the factor analysis, as shown in Table 5.

The new correlation matrix was calculated using only the remaining variables. Full correlation matrices are presented in Appendix A. All variables are correlated, with correlation coefficients higher than 0.2 .

The variable ratio for the current study's data was 1:12. The Kaiser-Meyer-Olkin (KMO) measure of sampling adequacy (Kaiser, 1970; Kaiser \& Mark, 1974) is suggested in cases where the variable ratio is less than 1:5. In the current study (with a ratio of 1:12), only Bartlett's (1950) test of sphericity was required. Bartlett's test is used to test the null hypothesis: the correlation matrix is an identity, and the counted significance level is less than 0.05 . The latter test proved significant (see Table 6), and factor analysis is therefore appropriate for the studied datasets. 
Table 5 | Excluded variables

\begin{tabular}{|c|c|c|c|}
\hline \multicolumn{2}{|c|}{ USA } & \multicolumn{2}{|c|}{$\mathbf{C Z}$} \\
\hline Men & Women & Men & Women \\
\hline \multicolumn{4}{|c|}{ Personal Impression } \\
\hline \multirow{2}{*}{ Stimulated } & \multirow{2}{*}{ Agitated } & Stimulated & Stimulated \\
\hline & & Excited & Excited \\
\hline \multirow{2}{*}{ Controlling } & \multirow{2}{*}{ Controlling } & Autonomous & Autonomous \\
\hline & & Dominant & Dominant \\
\hline \multirow{2}{*}{ Influential } & \multirow{2}{*}{ Influential } & Influential & Influential \\
\hline & & Controlling & Controlling \\
\hline Dominant & Dominant & Agitated & Agitated \\
\hline Autonomous & Autonomous & Frenzied & Frenzied \\
\hline \multicolumn{4}{|c|}{ Spoken Words } \\
\hline $\begin{array}{l}\text { The content of speech } \\
\text { was fully clear and well- } \\
\text { articulated. }\end{array}$ & \multirow{2}{*}{$\begin{array}{l}\text { The tone does relate to } \\
\text { the overall impact of the } \\
\text { content and the style. }\end{array}$} & \multirow{2}{*}{ None } & \multirow{2}{*}{ None } \\
\hline $\begin{array}{l}\text { The supporting argument } \\
\text { content of speech was } \\
\text { logically structured. }\end{array}$ & & & \\
\hline \multicolumn{4}{|c|}{ Authentic Perception } \\
\hline $\begin{array}{l}\text { He is aiming to be } \\
\text { himself rather than to } \\
\text { be popular. }\end{array}$ & $\begin{array}{l}\text { He is aiming to be } \\
\text { himself rather than to } \\
\text { be popular. }\end{array}$ & \multirow{8}{*}{$\begin{array}{l}\text { He has a high level } \\
\text { of self-esteem. }\end{array}$} & \multirow{3}{*}{$\begin{array}{l}\text { He has a high level } \\
\text { of self-esteem. }\end{array}$} \\
\hline He is true to himself. & He is true to himself. & & \\
\hline $\begin{array}{l}\text { He communicates } \\
\text { according to his values } \\
\text { and beliefs. }\end{array}$ & $\begin{array}{l}\text { He communicates } \\
\text { according to his values } \\
\text { and beliefs. }\end{array}$ & & \\
\hline $\begin{array}{l}\text { He communicates } \\
\text { authentically. }\end{array}$ & $\begin{array}{l}\text { He communicates } \\
\text { authentically. }\end{array}$ & & \multirow{5}{*}{$\begin{array}{l}\text { He feels alienated } \\
\text { from himself. }\end{array}$} \\
\hline $\begin{array}{l}\text { He is giving his own } \\
\text { opinion. }\end{array}$ & $\begin{array}{l}\text { He is giving his own } \\
\text { opinion. }\end{array}$ & & \\
\hline $\begin{array}{l}\text { He is not influenced by } \\
\text { others. }\end{array}$ & $\begin{array}{l}\text { He is not influenced by } \\
\text { others. }\end{array}$ & & \\
\hline $\begin{array}{l}\text { He feels alienated from } \\
\text { himself. }\end{array}$ & $\begin{array}{l}\text { He feels alienated from } \\
\text { himself. }\end{array}$ & & \\
\hline $\begin{array}{l}\text { He has a high level of } \\
\text { self-esteem. }\end{array}$ & $\begin{array}{l}\text { He has a high level of } \\
\text { self-esteem. }\end{array}$ & & \\
\hline
\end{tabular}


Table 6 | Bartlett's Test of Sphericity

\begin{tabular}{|l|l|r|}
\hline \multirow{3}{*}{ Bartlett's test of sphericity for men, USA } & App. ChiSquare & 2012.445 \\
& Df & 1567 \\
& Sig. & 0.000 \\
\hline \multirow{3}{*}{ Bartlett's test of sphericity for women, USA } & App. ChiSquare & 1909.771 \\
& Df & 1203 \\
\hline \multirow{3}{*}{ Bartlett's test of sphericity for men, CZ } & App. ChiSquare & 0.000 \\
\hline & Df & 2101.312 \\
\hline \multirow{3}{*}{ Bartlett's test of sphericity for women, CZ } & Sig. & 675 \\
& App. ChiSquare & 0.001 \\
\hline & Df & 1763.987 \\
& Sig. & 1434 \\
\hline
\end{tabular}

The purpose of data extraction is to condense a large number of items into a set of factors. When determining these factors, the simultaneous use of multiple decision rules is recommended (Thompson \& Daniel, 1996). Hair et al. (1995) confirmed this point by highlighting that the majority of factor analysts use several criteria. Typical criteria include Kaiser's criteria (eigenvalue greater than 1), the Scree test (Cattell, 1966), and the cumulative percentage of variance extracted (Horn, 1965) (see Table 7).

Table 7 | Eigenvalues

\begin{tabular}{|l|c|c|c|c|c|c|c|c|}
\hline & \multicolumn{2}{|c|}{ Men, USA } & \multicolumn{2}{c|}{ Men, Czech Republic } & \multicolumn{2}{c|}{ Women, USA } & \multicolumn{2}{c|}{$\begin{array}{c}\text { Women, Czech } \\
\text { Republic }\end{array}$} \\
\hline Index & $\begin{array}{l}\text { Eigen- } \\
\text { values }\end{array}$ & $\begin{array}{c}\text { Cumula- } \\
\text { tive per- } \\
\text { centage }\end{array}$ & $\begin{array}{c}\text { Eigen- } \\
\text { values }\end{array}$ & $\begin{array}{c}\text { Cumula- } \\
\text { tive per- } \\
\text { centage }\end{array}$ & $\begin{array}{c}\text { Eigen- } \\
\text { values }\end{array}$ & $\begin{array}{c}\text { Cumula- } \\
\text { tive per- } \\
\text { centage }\end{array}$ & $\begin{array}{c}\text { Eigen- } \\
\text { values }\end{array} \begin{array}{c}\text { Cumula- } \\
\text { tive per- } \\
\text { centage }\end{array}$ \\
\hline $\mathbf{1}$ & 3.525 & 45.54 & 2.214 & 44.88 & 2.978 & 40.98 & 4.121 & 59.60 \\
\hline $\mathbf{2}$ & 2.315 & 88.81 & 1.798 & 84.00 & 1.140 & 80.97 & 3.199 & 84.72 \\
\hline $\mathbf{3}$ & 0.915 & 97.79 & 1.110 & 98.25 & 0.401 & 95.27 & 1.100 & 98.79 \\
\hline $\mathbf{4}$ & 0.002 & 100.00 & 0.641 & 100.00 & 0.015 & 100.00 & 0.040 & 100.00 \\
\hline
\end{tabular}

The eigenvalues for the case "Men, USA" are greater than one for two factors, as are the eigenvalues for the case of "Women, CZ". Based on the above decision rules, the authors concluded that the datasets "Men, USA" and "Women, USA" should be analysed for two factors. The datasets for "Men, CZ" and "Women, CZ" were analysed for three factors, since the eigenvalues in these two cases are greater than one for three factors.

The next four tables (Tables 8 to 11) present the balance factors for each factor; in other words, the numeric value shows the correlation between the variables and factors.

As can be seen from Table 8, the first factor is most affected by the variable "Pleased" $(0.8930)$, followed by the variable "Satisfied" $(0.828)$, then by the variable "Happy" (0.813), and finally by the variable "Contented" $(0.402)$. The second factor is most affected by the following variables (in order of importance): “The speaker's points 
flow logically from one to the next"; "The content of speech is fully clear and well-articulated"; "The supporting argument content of speech is logically structured"; "The content and style of the speech does refer to what is spoken"; "The tone does relate to the overall impact of the content and the style"; and "The speaker is convincing". Table 9 displays the correlations between factors and variables for the case of "Women, Czech Republic".

Table 8 | Factor Loadings - Correlations between Factors and Variables (Men, Czech Republic)

\begin{tabular}{|c|r|r|l|}
\hline $\begin{array}{c}\text { Latent } \\
\text { Factor } \mathbf{1}\end{array}$ & $\begin{array}{c}\text { Latent } \\
\text { Factor } \mathbf{2}\end{array}$ & $\begin{array}{r}\text { Latent } \\
\text { Factor } 3\end{array}$ & \\
\hline 0.813 & -0.011 & -0.040 & Happy \\
\hline 0.893 & -0.053 & -0.047 & Pleased \\
\hline 0.828 & -0.098 & 0.099 & Satisfied \\
\hline 0.402 & 0.115 & -0.194 & Contented \\
\hline-0.184 & 0.822 & -0.064 & The content of speech is fully clear and well-articulated. \\
\hline 0.005 & 0.808 & -0.037 & The supporting argument content of speech is logically structured. \\
\hline-0.040 & 0.840 & -0.048 & The speaker's points flow logically from one to the next. \\
\hline 0.045 & 0.634 & -0.039 & The content and style of the speech does refer to what is spoken. \\
\hline 0.143 & 0.442 & 0.193 & The speaker is convincing. \\
\hline 0.116 & 0.443 & 0.135 & The tone does relate to the overall impact of the content and the style. \\
\hline-0.028 & -0.063 & 0.784 & He is aiming to be himself rather than to be popular. \\
\hline 0.042 & -0.089 & 0.786 & He is true to himself. \\
\hline-0.012 & 0.133 & 0.572 & He communicates according to his values and beliefs. \\
\hline 0.093 & -0.018 & 0.665 & He communicates authentically. \\
\hline-0.138 & -0.010 & 0.718 & He is giving his own opinion. \\
\hline 0.083 & -0.032 & 0.469 & He is not influenced by others. \\
\hline-0.040 & 0.088 & 0.239 & He feels alienated from himself. \\
\hline
\end{tabular}


Table 9 | Factor Loadings - Correlations Between Factors and Variables (Women, Czech Republic)

\begin{tabular}{|c|c|c|l|}
\hline $\begin{array}{c}\text { Latent } \\
\text { Factor 1 }\end{array}$ & $\begin{array}{c}\text { Latent } \\
\text { Factor } \mathbf{2}\end{array}$ & $\begin{array}{c}\text { Latent } \\
\text { Factor }\end{array}$ & \multicolumn{1}{|c|}{ Variables } \\
\hline 0.870 & -0.078 & -0.002 & Happy \\
\hline 0.814 & 0.046 & -0.043 & Pleased \\
\hline 0.899 & 0.002 & -0.036 & Satisfied \\
\hline 0.466 & -0.006 & 0.056 & Contented \\
\hline-0.122 & 0.781 & 0.049 & The content of speech is fully clear and well-articulated. \\
\hline-0.017 & 0.941 & -0.107 & The supporting argument content of speech is logically structured. \\
\hline 0.006 & 0.869 & -0.034 & The speaker's points flow logically from one to the next. \\
\hline 0.099 & 0.582 & 0.137 & The content and style of the speech does refer to what is spoken. \\
\hline 0.098 & 0.497 & 0.131 & The speaker is convincing. \\
\hline 0.055 & 0.567 & 0.120 & The tone does relate to the overall impact of the content and the style. \\
\hline 0.043 & -0.042 & 0.716 & He is aiming to be himself rather than to be popular. \\
\hline-0.024 & 0.012 & 0.773 & He is true to himself. \\
\hline-0.057 & 0.034 & 0.709 & He communicates according to his values and beliefs. \\
\hline-0.074 & 0.066 & 0.668 & He communicates authentically. \\
\hline-0.021 & -0.022 & 0.653 & He is giving his own opinion. \\
\hline 0.055 & -0.218 & 0.670 & He is not influenced by others. \\
\hline
\end{tabular}

As can be seen from Table 9, the first factor is most affected by the variable "The supporting argument content of speech is logically structured" (0.941). The second variable is "The speaker's points flow logically from one to the next" $(0.869)$; the third is "The content of speech is fully clear and well-articulated" $(0.781)$; the next is "The content and style of the speech does refer to what is spoken" $(0.582)$; then "The tone does relate to the overall impact of the content and the style" $(0.567)$; and the last is "The speaker is convincing" $(0.497)$. The second factor is most affected by the variable "Satisfied" $(0.899)$, then by "Happy" (0.870), then "Pleased" (0.814), and lastly by "Contented" (0.466). The third factor is most affected by the variable "He is true to himself" $(0.773)$, then by "He is aiming to be himself rather than to be popular" (0.716), then by "He communicates according to his values and beliefs" (0.709), then "He is not influenced by others" $(0.670)$, then "He communicates authentically" $(0.668)$, and lastly by "He is giving his own opinion" (0.653). Tables 10 and 11 give the correlations between factors and variables for the cases "Men, USA" and "Women, USA". 
Table 10 | Factor Loadings - Correlations between Factors and Variables (Men, USA)

\begin{tabular}{|c|r|l|}
\hline $\begin{array}{c}\text { Latent } \\
\text { Factor } \mathbf{1}\end{array}$ & $\begin{array}{r}\text { Latent } \\
\text { Factor } \mathbf{2}\end{array}$ & \\
\hline 0.876 & 0.001 & Happy \\
\hline 0.947 & 0.002 & Pleased \\
\hline 0.894 & -0.088 & Satisfied \\
\hline 0.815 & 0.074 & Contented \\
\hline 0.689 & -0.009 & Excited \\
\hline 0.701 & -0.006 & Frenzied \\
\hline 0.488 & 0.057 & Agitated \\
\hline 0.001 & 0.654 & The speaker's points flow logically from one to the next. \\
\hline 0.010 & 0.697 & The content and style of the speech does refer to what is spoken. \\
\hline-0.005 & 0.432 & The speaker is convincing. \\
\hline 0.005 & 0.452 & The tone does relate to the overall impact of the content and the style. \\
\hline
\end{tabular}

Table 11 | Factor Loadings - Correlations between Factors and Variables (Women, USA)

\begin{tabular}{|c|r|l|}
\hline $\begin{array}{c}\text { Latent } \\
\text { Factor 1 }\end{array}$ & $\begin{array}{c}\text { Latent } \\
\text { Factor } 2\end{array}$ & \\
\hline 0.819 & -0.007 & Happy \\
\hline 0.834 & -0.007 & Pleased \\
\hline 0.845 & -0.041 & Satisfied \\
\hline 0.780 & 0.010 & Contented \\
\hline 0.531 & 0.001 & Excited \\
\hline 0.771 & 0.001 & Frenzied \\
\hline 0.640 & 0.002 & Stimulated \\
\hline-0.014 & 0.758 & The speaker's points flow logically from one to the next. \\
\hline 0.007 & 0.625 & The content and style of the speech does refer to what is spoken. \\
\hline 0.004 & 0.599 & The speaker is convincing. \\
\hline 0.002 & 0.789 & The supporting argument content of speech is logically structured. \\
\hline
\end{tabular}

The purpose of the rotation step is to simplify the factor structure of a group of items (Costello \& Osborne, 2005). Rotation maximizes high item loadings and minimizes low item loadings, thus producing a simplified solution that is easier to interpret. There are two rotation techniques: orthogonal (varimax/quartimax) and oblique (olbimin/ 
promax) rotation. Orthogonal varimax rotation, first developed by Thompson (2004), is the most common rotational technique and produces factor structures that are uncorrelated. Oblique rotation produces correlated factors. Results are often considered more accurate for research involving human behaviours, or when data does not meet a priori assumptions (Costello \& Osborne, 2005). Regardless of which rotation method is used, the primary objective is to provide parsimonious solutions that are easy to interpret (Kieffer, 1999).

To conclude the analysis, data obtained from the survey and video coding were merged and standardized for analysis using MATLAB. The quality of the collected data was assessed in terms of outliers, missing values, skewness and kurtosis. All tested values were within the acceptable range, according to Bortz and Doering (2006). The most common factor model is a multivariate linear model (Tucker \& MacCallum, 1997), in which scores that are assigned weights and added together are defined as factors of the resulting variables (Gorsuch, 2015). Factor loadings and rotations were used to calculate the factor scores, and the variables included within each factor were then determined. The correlations between the obtained factors were then calculated, and the results indicated insignificant correlations between obtained factors.

\section{Results}

Each dataset (U.S. and Czech Republic) was divided according to gender. The resulting four groups were subjected to factor analysis. The main task of this factor analysis was to uncover the latent factors which can explain the relationship between the observed variables. There are two latent factors for both the "Men, U.S." and the "Women, U.S." datasets. For the "Men, Czech Republic" and "Women, Czech Republic" datasets, there are three latent factors.

For the groups "Men, U.S." and "Men, Czech Republic", the Personal Impression factor (Pleased, Satisfied, Happy, and Contented) was the most important factor influencing positive impressions in personal selling situations. For the "Men, U.S. group", the second half of latent factor 1 is: Frenzied, Excited, Agitated. Spoken Word is the second latent factor for the "Men, U.S." group. and for the "Men, Czech Republic" group, the second latent factor was Spoken Words ("The speaker's points flow logically from one to the next", "The content of speech is fully clear and well-articulated", "The supporting argument content of speech is logically structured", "The content and style of the speech does refer to what is spoken", "The tone does relate to the overall impact of the content and the style", and "The speaker was convincing"). The third latent factor for the "Male, Czech Republic" group, Authentic Perception ("He is true to himself", "He is aiming to be himself rather than to be popular", "He is giving his own opinion", "He communicates authentically", "He communicates according to his values and beliefs", "He is not influenced by others", "He feels alienated from himself") was next.

Similarly to the male groups, the female groups ("Women, U.S." and "Women, Czech Republic") show several differences. The Personal Impression variable (Satisfied, Pleased, Happy, Contented, Frenzied, Stimulated and Excited) was most important for U.S. females, while the Spoken Words variable ("The supporting argument content of speech is logically structured", "The speaker's points flow logically from one to the next", "The content of speech is fully clear and well-articulated", "The content and style of the speech does refer 
to what is spoken", "The tone does relate to the overall impact of the content and the style", "The speaker is convincing") was most important for Czech women.

For U.S. women, the second most important variable was Spoken Words, whereas for Czech women (in a similar way to Czech men) Authentic Perception was important ("He is true to himself", "He is aiming to be himself rather than to be popular", "He is giving his own opinion", "He communicates authentically", "He communicates according to his values and beliefs", "He is not influenced by others").

From a national perspective, the main difference between the U.S. and Czech customers, for both males and females, involved Authentic Perception. Czech respondents were sensitive to the authenticity of the salesperson, while U.S. respondents were not affected by this dimension.

\section{Conclusions}

Based on the research findings, several practical conclusions can be identified. Conclusions will enable marketing managers, consultants, and business partners operating in the U.S. and/or Czech Republic to improve the efficacy of their applied marketing activities. Specific conclusions are as follows:

- Salesperson authenticity is more relevant in the Czech market. The cautious and indirect interaction (strong communication context) features of Czech culture likely drive this (Nový \& Schroll-Machl, 2005). The relevance of authenticity has been demonstrated in previous research (Walumbwa et al., 2010).

- Personal impressions and the content of the sales talk are relevant in both the U.S. and Czech Republic. This conclusion supports Ambady et al.'s (1993, 2006) results, which highlighted the relevance of the first impression in sales.

Consequently, variant sales personalities and approaches should be used in the U.S. versus the Czech Republic. In the latter, a salesperson who shows a high level of product competence is more likely to succeed. In the U.S., a salesperson who demonstrates a high level of confidence and who provides a persuasive presentation is more likely to be successful. Therefore, hiring manager and training managers in the U.S. and Czech Republic should use variant personality hiring rubrics and training schemas in order to maximize sales effectiveness in their respective geographic regions. This recommendation is further supported by the intercultural differences discussed in the current paper's introductory section (see Hall \& Hall, 1990; Hampden-Turner \& Trompenaars., 1990; Nový \& Schroll-Machl, 2003; Nový \& Schroll-Machl, 2005; Ort et al., 2002; Stewart \& Benett, 1991)

\section{Limitations and Directions for Future Research}

Although the methodology used in the current study resulted in an acceptable level of reliability and validity, limitations still exist. First, the study did not examine the impact of attractiveness and gender. Both the male and female actors were attractive (good-looking), but the influence of attractiveness on customers' perceptions (as well as gender) was not investigated. Since the effect of attractiveness has been documented (Randall, 1990; 
Ahearne et al., 1999), managers should recognize and incorporate the effect of attractiveness in training scenarios. Additional research on this matter is recommended.

Second, the location of the study offers a potential limitation. The fact that the experiment was conducted using an automotive dealership in the United States raises the question of whether the findings can be generalized to other business markets and varying cultural environments.

Another possible limitation might arise from the fact that university students were used as participants rather than existing customers. However, taking into account that the students are potential automotive customers, we do not view this limitation as significant.

Regarding future research, there is need to study the influence of other marketing factors in relation to the derived model. In particular, marketing activities related to product, pricing, distribution, and promotional activities should be assessed in terms of the suggested ABC model. Additionally, a comparison to other markets or regions may also be valuable.

\section{References}

Ahearne, M., Gruen, T. W., \& Burke-Jarvis, C. (1999). If looks could sell: Moderation and mediation of the attractiveness effect on salesperson performance. International Journal of Research in Marketing, 16(4), 269-284.

Algera, P. M., \& Lips-Wiersma, M. (2012). Radical authentic leadership: Co-creating the conditions under which all members of the organization can be authentic. The Leadership Quarterly, 23(1), 118-131.

Ambady, N., \& Rosenthal, R. (1993). Half a minute: Predicting teacher evaluations from thin slices of nonverbal behaviour and physical attractiveness. Journal of Personality and Social Psychology, 64(3), 431-441.

Ambady, N., Krabbenhoft, M., \& Hogan, D. (2006). The 30-Sec sale: Using thin-slice judgments to evaluate sales effectiveness. Journal of Consumer Psychology, 16(1), 4-13.

Avolio, B. J., \& Gardner, W. L. (2005). Authentic leadership development: Getting to the root of positive forms of leadership. The Leadership Quarterly, 6(3), 801-823.

Avolio, B. J., Gardner, W. L, Walumbwa, F. O., Luthans, F., \& May, D. R. (2004). Unlocking the mask: a look at the process by which authentic leaders impact follower attitudes and behaviors. The Leadership Quarterly, 15(6), 801-823.

Bakeman, R. (2000). Behavioral observations and coding. In H. T. Reis \& C. K. Judd (Eds.), Handbook of research methods in social psychology. New York: Cambridge University Press.

Barrett-Lennard, G. T. (1998). Carl Rogers' helping system: Journey and substance. London: Sage.

Bartlett, M. S. (1950). Tests of significance in factor analysis. British Journal of Psychology, 3, 77-85.

Bauer, J. (2002). Das gedächtnis des körpers - wie beziehungen und lebensstile unsere gene steuern. Frankfurt: Eichborn.

Bedrnová, E., \& Nový, I. (2007). Psychologie a sociologie řízení. Prague: Management Press.

Bethell, E. J., Vick, S., \& Bard, K. A. (2007). Measurement of eye-gaze in chimpanzees. American Journal of Primatology, 69(5), 562-575.

Bortz, J., \& Doering, N. (2006). Forschungsmethoden und evaluation, Vol. 4, Heidelberg, Germany: Springer.

Bowker, A., Boekhoven, B., Nolan, A., Bauhaus, S., Glover, P., Powell, T., \& Taylor, S. (2009). Naturalistic observations of spectator behavior at youth hockey games. The Sport Psychologist, 23(1), 301-316. 
Busha, A. J., Smart, D., \& Nicholsa, E. N. (2002). Pursuing the concept of marketing productivity Introduction to the JBR Special Issue on Marketing Productivity. Journal of Business Research, 55(5), 343-347.

Cattell, R. B. (1966). The scree test for the number of factors. Multivariate Behavioural Research, 1(2), 245-76.

Child, D. (1990). The essentials of factor analysis. $2^{\text {nd }} \mathrm{ed}$. London: Cassel Educational Limited.

Costello, A. B., \& Osborne, J. W. (2005). Best practices in exploratory factor analysis: Four recommendations for getting the most from your analysis. Practical Assessment, Research \& Evaluation, 10(7), 1-9.

Crick, N. R., Ostrov, J.M., Burr, J.E., Jansen-Yeh, E.A., Cullerton-Sen, C., \& Ralston, P. (2006). A longitudinal study of relational and physical aggression in preschool. Journal of Applied Developmental Psychology, 27(3), 254-268.

Damásio, A. R., Damásio, H., \& van Straten, G. (1996). Neurobiology of decision-making. Berlin: Springer.

Diddams, M., \& Chang, G. C. (2012). Only human: Exploring the nature of weakness in authentic leadership. The Leadership Quarterly, 23(3), 593-603.

Erevelles, S., \& Fukawa, N. (2013). The role of affect in personal selling and sales management. Journal of Personal Selling \& Sales Management, 18(1), 7-24.

Fabrigar, L. R., Wegener, D. T., MacCallum, R. C., \& Strahan, E. J. (1999). Evaluating the use of exploratory factor analysis in psychological research. Psychological Methods, 4(3), 272-299.

Freud, S. (1938). Abriss der psychoanalyse. Frankfurt: Fischer.

Gorsuch, R. L. (2015). Factor analysis. New York: Psychology Press and Routledge Classic Editions.

Gudykunst, W. B. (2004). Bridging Differences: Effective Intergroup Communication, 4th. ed. Thousand Oaks, California: Sage Publications.

Hair J., Anderson, R. E., Tatham, R. L., \& Black, W. C. (1995). Multivariate data analysis. 4th ed. New Jersey: Prentice-Hall Inc.

Hall, E. T. (1976). Beyond culture. Garden City, NY: Anchor'.

Hall, E. T., \& Hall, M. (1990). Understanding cultural differences. 1st ed. Boston: Intercultural Press.

Hampden-Turner, F., \& Trompenaars, C. (1999). Riding the waves of culture: understanding cultural diversity in business. London: Nicholas Brealey Publications.

Havlena, W. J., \& Holbrook, M. B. (1986). The varieties of consumption experience: Comparing two typologies of emotion in consumer behavior. Journal of Consumer Research, 13(3), 394-404.

Henson, R. K., \& Roberts, J. K. (2006). Use of exploratory factor analysis in published research: common errors and some comment on improved practice. Educational and Psychological Measurement, 66(3), 393-416.

Hofstede, G. (2011). Dimensionalizing cultures: The Hofstede model in context. Online Readings in Psychology and Culture, 2(1), 8.

Horn, J. L. (1965). A rationale and test for the number of factors in factor analysis. Psychometrika, 30(2), 179-85.

Huck, S. W. (2012). Reading statistics and research. Boston, MA: Pearson.

Jöreskog, K. G. (1969). A general approach to confirmatory maximum likelihood factor analysis. Psychometrika, 23, 187-200. 
Kaiser, H. F. (1970). A second-generation little jiffy. Psychometrika, 35(4), 401-415.

Kaiser, H. F., \& Mark, I. V. (1974). Little jiffy. Educational and Psychological Measurement, 34(1), 111-117.

Kernis, M. H. (2003). Toward a conceptualization of optimal self-esteem. Psychological Inquiry, 14(1), 1-26.

Kieffer, K. M. (1999). An introductory primer on the appropriate use of exploratory and confirmatory factor analysis. Research in Schools, 6(2), 75-92.

Kolman, L., Noorderhaven, N. G., Hofstede, G., \& Dienes, E. (2003). Cross-cultural differences in Central Europe. Journal of Managerial Psychology, 18(1), 76-88.

Mehrabian, A. (1972). Nonverbal communication. Chicago, Illinois: Aldine-Atherton.

Meloun, M., \& Militký, J. (2006). Kompendium statistického zpracování dat: metody a řešené úlohy, Praha: Academia.

Neider, L. L., \& Schriesheim, C. A. (2011). The authentic leadership inventory (ALI): Development and empirical tests. The Leadership Quarterly, 22(6), 1146-1164.

Nock, M. K., \& Kurtz, S. (2005). Direct behavioral observation in school settings: Bringing science to practice. Journal of Cognitive and Behavioral Practice, 12(3), 359-370.

Norderhaven, N., Hofstede, G., \& Dienes, E. (2003). Cross-cultural differences in Central Europe, Journal of Managerial Psychology, 18(1/2), 76-88.

Nový, I., \& Schroll-Machl, S. (2003). Interkulturní komunikace v rízení a podnikání, Prague: Management Press.

Nový, I., \& Schroll-Machl, S. (2005). Spolupráce přes hranice kultur. $1^{\text {st }}$ edition, Prague: Management Press.

Ort, A., Krines, V., \& Veselý, Z. (2002). Zahraniční politika České republiky, Prague: Oeconomica.

Ostrov J. M., \& Keating, C. F. (2004). Gender differences in preschool aggression during free play and structured interactions: An observational study. Social Development, 13(2), 255-277.

Parsons, T., \& Shils, E. A. (1951). Toward a general theory of action. Cambridge, MA: Harvard University Press.

Pellegrini, A. D. (2004). Observing children in their natural worlds: A methodological primer. 2nd. Edition. Mahwah, NJ: Lawrence Erlbaum Associates.

Pett, M., Lackey, N. \& Sullivan, J. (2003). Making sense of factor analysis. Thousand Oaks, CA: Sage Publications, Inc.

Petty, R .E., \& Cacioppo, J. T. (1986). The Elaboration likelihood model of persuasion. Advances in Experimental Social Psychology, 19(2), 123-189.

Plouffe, C. R., Williams, B., \& Wacliner, T. (2008). Navigating difficult waters: Publishing trends and scholarship in sales research. Journal of Personal Selling \& Sales Management, 28(1), 79-92.

Randall, E. J. (1990). Review of salesperson selection techniques and criteria: A managerial approach. International Journal of Research in Marketing, 7(2-3), 81-96.

Rego, A., Sousa, F. Marques, C., \& Pina e Cunha, M. (2011). Authentic leadership promoting employees' psychological capital and creativity. Journal of Business Research, 65(3), 429-437. 
Samovar, L. A., \& Porter, R. E. (2003). Intercultural communication: A reader, 10th ed. Wadsworth: Belmont.

Sheth, J. N., \& Sisodia, R. S. (2002). Marketing productivity Issues and analysis. Journal of Business Research, 55(5), 349-362.

Solomon, M., Bamossy, G., \& Askegaard, S. (2003). Konsumentenverhalten - Der europäische markt. New Jersey: Pearson.

Stewart, E. C., \& Benett, M. J. (1991). American cultural patterns: a cross-cultural perspective. Yarmouth, ME: Intercultural Press.

Tabachnick, B. G., \& Fidell, L. S. (2007). Using multivariate statistics. Boston: Pearson Education Inc.

Tate, B. (2009). A longitudinal study of the relationships among self-monitoring, authentic leadership, and perceptions of leadership. Journal of Leadership and Organizational Studies, 15(1), 16-29.

Swisher, L. L, Beckstead, J. W., \& Bebeau, M. J. (2004). Factor analysis as a tool for survey analysis using a professional role orientation inventory as an example. Physical Therapy, 84(9), 784-799.

Thompson B., \& Daniel, L.G. (1996). Factor analytic evidence for the construct validity of scores: A historical overview and some guidelines. Educational and Psychological Measurement, 56(2), 197-208.

Tucker, L. R., \& MacCallum, R.C. (1997). Exploratory factor analysis. Unpublished manuscript.

Walumbwa, F. O., Hui Wang, P. W., Schaubroeck, J., \& Avolio, B. J. (2010). Psychological processes linking authentic leadership to follower behaviors. The Leadership Quarterly, 21(5), 901-914.

Wiemann, J. M. (1977). Explication and test of a model of communicative competence. Human Communication Research, 3(3), 195-213.

Wood, A. M., Linley, P. A., Maltby, J., Baliousis, M., \& Joseph, S. (2008). The authentic personality: A theoretical and empirical conceptualization and the development of the authenticity scale. Journal of Counseling Psychology, 55(3), 385-399.

\section{Authors}

\section{David Ř́ha}

Assistant Professor of Sales and Marketing

Faculty of Business Administration

University of Economics, Prague, Czech Republic,

david.riha@vse.cz

\section{Timothy Heinze}

Executive Director of the Professional Sales Program

Associate Professor of Marketing

College of Business, California State University, Chico

tcheinze@csuchico.edu

\section{Michael Stros}

Head of Marketing Group

University of Applied Sciences and Arts of Southern Switzerland (SUPSI)

Fernfachhochschule Schweiz, Brig, Switzerland,

michael.stros@ffhs.ch 


\section{Appendix A: Correlation matrices}

Note: $\mathrm{X}$ denotes respective variables - see Tables 8 to 11 for their description.

Table A.1 | Correlation Matrix (Men, USA)

\begin{tabular}{|c|c|c|c|c|c|c|c|c|c|c|c|}
\hline & $\mathbf{X 1}$ & $\mathbf{X 2}$ & $\mathbf{X 3}$ & $\mathbf{X 4}$ & $\mathbf{X 5}$ & $\mathbf{X 6}$ & $\mathbf{X 7}$ & $\mathbf{X 8}$ & $\mathbf{X 9}$ & $\mathbf{X 1 0}$ & $\mathbf{X 1 1}$ \\
\hline $\mathbf{X 1}$ & 1.000 & 0.698 & 0.696 & 0.385 & 0.553 & 0.389 & 0.391 & 0.395 & 0.341 & 0.396 & 0.420 \\
\hline $\mathbf{X 2}$ & 0.698 & 1.000 & 0.725 & 0.376 & 0.335 & 0.279 & 0.416 & 0.325 & 0.248 & 0.217 & 0.373 \\
\hline $\mathbf{X 3}$ & 0.696 & 0.725 & 1.000 & 0.383 & 0.356 & 0.296 & 0.440 & 0.323 & 0.380 & 0.304 & 0.402 \\
\hline $\mathbf{X 4}$ & 0.385 & 0.376 & 0.383 & 1.000 & 0.351 & 0.360 & 0.391 & 0.357 & 0.470 & 0.376 & 0.231 \\
\hline $\mathbf{X 5}$ & 0.553 & 0.335 & 0.356 & 0.351 & 1.000 & 0.331 & 0.375 & 0.357 & 0.387 & 0.235 & 0.299 \\
\hline $\mathbf{X 6}$ & 0.389 & 0.279 & 0.296 & 0.360 & 0.331 & 1.000 & 0.400 & 0.233 & 0.202 & 0.318 & 0.209 \\
\hline $\mathbf{X 7}$ & 0.391 & 0.416 & 0.440 & 0.391 & 0.375 & 0.400 & 1.000 & 0.254 & 0.333 & 0.365 & 0.441 \\
\hline $\mathbf{X 8}$ & 0.395 & 0.325 & 0.323 & 0.357 & 0.357 & 0.233 & 0.254 & 1.000 & 0.417 & 0.337 & 0.493 \\
\hline $\mathbf{X 9}$ & 0.341 & 0.248 & 0.380 & 0.470 & 0.387 & 0.202 & 0.333 & 0.417 & 1.000 & 0.521 & 0.583 \\
\hline $\mathbf{X 1 0}$ & 0.396 & 0.217 & 0.304 & 0.376 & 0.235 & 0.318 & 0.365 & 0.337 & 0.521 & 1.000 & 0.474 \\
\hline $\mathbf{X 1 1}$ & 0.420 & 0.373 & 0.402 & 0.231 & 0.299 & 0.209 & 0.441 & 0.493 & 0.583 & 0.474 & 1.000 \\
\hline
\end{tabular}

Table A.2 | Correlation Matrix (Men, Czech Republic)

\begin{tabular}{|c|c|c|c|c|c|c|c|c|c|c|c|c|c|c|c|c|c|}
\hline & $\mathbf{X} 1$ & $\times 2$ & X3 & X4 & $\times 5$ & X6 & X7 & X8 & X9 & X10 & X11 & X12 & X13 & X14 & X15 & X16 & X17 \\
\hline $\mathbf{X} 1$ & 1.000 & 0.299 & 0.252 & 0.258 & 0.380 & 0.420 & 0.349 & 0.402 & 0.482 & 0.412 & 0.468 & 0.442 & 0.276 & 0.432 & 0.449 & 0.240 & 0.287 \\
\hline$\times 2$ & 0.299 & 1.000 & 0.624 & 0.631 & 0.460 & 0.389 & 0.428 & 0.268 & 0.282 & 0.349 & 0.244 & 0.258 & 0.321 & 0.317 & 0.271 & 0.240 & 0.287 \\
\hline X3 & 0.252 & 0.624 & 1.000 & 0.685 & 0.564 & 0.480 & 0.458 & 0.249 & 0.300 & 0.313 & 0.301 & 0.247 & 0.372 & 0.345 & 0.370 & 0.271 & 0.287 \\
\hline X4 & 0.258 & 0.631 & 0.685 & 1.000 & 0.531 & 0.491 & 0.497 & 0.285 & 0.308 & 0.322 & 0.276 & 0.248 & 0.379 & 0.436 & 0.263 & 0.411 & 0.287 \\
\hline$\times 5$ & 0.380 & 0.460 & 0.564 & 0.531 & 1.000 & 0.489 & 0.477 & 0.256 & 0.263 & 0.300 & 0.305 & 0.310 & 0.476 & 0.382 & 0.303 & 0.277 & 0.287 \\
\hline X6 & 0.420 & 0.389 & 0.480 & 0.491 & 0.489 & 1.000 & 0.468 & 0.285 & 0.306 & 0.335 & 0.352 & 0.266 & 0.371 & 0.384 & 0.269 & 0.394 & 0.287 \\
\hline X7 & 0.349 & 0.428 & 0.458 & 0.497 & 0.477 & 0.468 & 1.000 & 0.316 & 0.282 & 0.272 & 0.295 & 0.252 & 0.311 & 0.376 & 0.322 & 0.294 & 0.287 \\
\hline X8 & 0.402 & 0.268 & 0.249 & 0.285 & 0.256 & 0.285 & 0.316 & 1.000 & 0.597 & 0.469 & 0.464 & 0.469 & 0.380 & 0.428 & 0.395 & 0.406 & 0.287 \\
\hline X9 & 0.482 & 0.282 & 0.300 & 0.308 & 0.263 & 0.306 & 0.282 & 0.597 & 1.000 & 0.505 & 0.505 & 0.478 & 0.375 & 0.380 & 0.342 & 0.407 & 0.287 \\
\hline $\mathrm{X} 10$ & 0.412 & 0.349 & 0.313 & 0.322 & 0.300 & 0.335 & 0.272 & 0.469 & 0.505 & 1.000 & 0.508 & 0.448 & 0.286 & 0.323 & 0.223 & 0.429 & 0.287 \\
\hline X11 & 0.468 & 0.244 & 0.301 & 0.276 & 0.305 & 0.352 & 0.295 & 0.464 & 0.505 & 0.508 & 1.000 & 0.473 & 0.315 & 0.346 & 0.218 & 0.423 & 0.287 \\
\hline $\mathrm{X} 12$ & 0.442 & 0.258 & 0.247 & 0.248 & 0.310 & 0.266 & 0.252 & 0.469 & 0.478 & 0.448 & 0.473 & 1.000 & 0.417 & 0.339 & 0.324 & 0.306 & 0.287 \\
\hline X13 & 0.276 & 0.321 & 0.372 & 0.379 & 0.476 & 0.371 & 0.311 & 0.380 & 0.375 & 0.286 & 0.315 & 0.417 & 1.000 & 0.347 & 0.278 & 0.307 & 0.287 \\
\hline X14 & 0.432 & 0.317 & 0.345 & 0.436 & 0.382 & 0.384 & 0.376 & 0.428 & 0.380 & 0.323 & 0.346 & 0.339 & 0.347 & 1.000 & 0.275 & 0.329 & 0.287 \\
\hline X15 & 0.449 & 0.271 & 0.370 & 0.263 & 0.303 & 0.269 & 0.322 & 0.395 & 0.342 & 0.223 & 0.218 & 0.324 & 0.278 & 0.275 & 1.000 & 0.323 & 0.287 \\
\hline X16 & 0.240 & 0.240 & 0.271 & 0.411 & 0.277 & 0.394 & 0.294 & 0.406 & 0.407 & 0.429 & 0.423 & 0.306 & 0.307 & 0.329 & 0.323 & 1.000 & 0.287 \\
\hline X17 & 0.287 & 0.348 & 0.289 & 0.355 & 0.377 & 0.300 & 0.380 & 0.406 & 0.411 & 0.411 & 0.355 & 0.323 & 0.322 & 0.412 & 0.424 & 0.441 & 1.000 \\
\hline
\end{tabular}


Table A.3 | Correlation Matrix (Women, USA)

\begin{tabular}{|c|c|c|c|c|c|c|c|c|c|c|c|}
\hline & $\mathbf{X 1}$ & $\mathbf{X 2}$ & $\mathbf{X 3}$ & $\mathbf{X 4}$ & $\mathbf{X 5}$ & $\mathbf{X 6}$ & $\mathbf{X 7}$ & $\mathbf{X 8}$ & $\mathbf{X 9}$ & $\mathbf{X 1 0}$ & $\mathbf{X 1 1}$ \\
\hline $\mathbf{X 1}$ & 1.000 & 0.702 & 0.646 & 0.327 & 0.281 & 0.275 & 0.327 & 0.247 & 0.420 & 0.333 & 0.381 \\
\hline $\mathbf{X 2}$ & 0.702 & 1.000 & 0.696 & 0.375 & 0.509 & 0.306 & 0.366 & 0.430 & 0.436 & 0.501 & 0.029 \\
\hline $\mathbf{X 3}$ & 0.646 & 0.696 & 1.000 & 0.338 & 0.403 & 0.278 & 0.376 & 0.457 & 0.367 & 0.206 & 0.251 \\
\hline $\mathbf{X 4}$ & 0.327 & 0.375 & 0.338 & 1.000 & 0.261 & 0.280 & 0.386 & 0.210 & 0.302 & 0.342 & 0.391 \\
\hline $\mathbf{X 5}$ & 0.281 & 0.509 & 0.403 & 0.261 & 1.000 & 0.395 & 0.245 & 0.221 & 0.266 & 0.397 & 0.235 \\
\hline $\mathbf{X 6}$ & 0.275 & 0.306 & 0.278 & 0.280 & 0.395 & 1.000 & 0.405 & 0.344 & 0.275 & 0.275 & 0.291 \\
\hline $\mathbf{X 7}$ & 0.327 & 0.366 & 0.376 & 0.386 & 0.245 & 0.405 & 1.000 & 0.287 & 0.303 & 0.321 & 0.271 \\
\hline $\mathbf{X 8}$ & 0.247 & 0.430 & 0.457 & 0.210 & 0.221 & 0.344 & 0.287 & 1.000 & 0.253 & 0.317 & 0.247 \\
\hline $\mathbf{X 9}$ & 0.420 & 0.436 & 0.367 & 0.302 & 0.266 & 0.275 & 0.303 & 0.253 & 1.000 & 0.510 & 0.617 \\
\hline $\mathbf{X 1 0}$ & 0.333 & 0.501 & 0.206 & 0.342 & 0.397 & 0.275 & 0.321 & 0.317 & 0.510 & 1.000 & 0.473 \\
\hline $\mathbf{X 1 1}$ & 0.381 & 0.029 & 0.251 & 0.391 & 0.235 & 0.291 & 0.271 & 0.247 & 0.617 & 0.473 & 1.000 \\
\hline
\end{tabular}

Table A.4 | Correlation matrix (Women, Czech Republic)

\begin{tabular}{|c|c|c|c|c|c|c|c|c|c|c|c|c|c|c|c|c|}
\hline & $\mathbf{X 1}$ & $\mathbf{X 2}$ & $\mathbf{X 3}$ & $\mathbf{X} 4$ & $\mathbf{X 5}$ & $\mathbf{X 6}$ & $\mathbf{X 7}$ & $\mathbf{X 8}$ & $\mathbf{X 9}$ & $\mathbf{X} 10$ & $\mathbf{X 1 1}$ & $\mathbf{X 1 2}$ & $\mathbf{X 1 3}$ & $\mathbf{X 1 4}$ & $\mathbf{X 1 5}$ & $\mathbf{X 1 6}$ \\
\hline $\mathbf{X 1}$ & 1.000 & 0.400 & 0.233 & 0.202 & 0.218 & 0.209 & 0.237 & 0.218 & 0.216 & 0.242 & 0.207 & 0.273 & 0.294 & 0.270 & 0.348 & 0.331 \\
\hline $\mathbf{X 2}$ & 0.400 & 1.000 & 0.254 & 0.233 & 0.265 & 0.241 & 0.296 & 0.381 & 0.378 & 0.303 & 0.332 & 0.343 & 0.394 & 0.412 & 0.414 & 0.405 \\
\hline $\mathbf{X 3}$ & 0.233 & 0.254 & 1.000 & 0.417 & 0.337 & 0.933 & 0.729 & 0.299 & 0.797 & 0.523 & 0.369 & 0.859 & 0.691 & 0.242 & 0.571 & 0.596 \\
\hline $\mathbf{X 4}$ & 0.202 & 0.233 & 0.417 & 1.000 & 0.521 & 0.583 & 0.309 & 0.507 & 0.571 & 0.729 & 0.719 & 0.361 & 0.649 & 0.496 & 0.767 & 0.346 \\
\hline $\mathbf{X 5}$ & 0.218 & 0.265 & 0.337 & 0.521 & 1.000 & 0.474 & 0.259 & 0.958 & 0.509 & 0.550 & 0.495 & 0.509 & 0.429 & 0.324 & 0.305 & 0.410 \\
\hline $\mathbf{X 6}$ & 0.209 & 0.241 & 0.933 & 0.583 & 0.474 & 1.000 & 0.379 & 0.357 & 0.728 & 0.485 & 0.505 & 0.438 & 0.323 & 0.308 & 0.315 & 0.408 \\
\hline $\mathbf{X 7}$ & 0.237 & 0.296 & 0.729 & 0.309 & 0.259 & 0.379 & 1.000 & 0.299 & 0.352 & 0.458 & 0.280 & 0.320 & 0.449 & 0.302 & 0.348 & 0.212 \\
\hline $\mathbf{X 8}$ & 0.218 & 0.381 & 0.299 & 0.507 & 0.958 & 0.357 & 0.299 & 1.000 & 0.624 & 0.631 & 0.460 & 0.389 & 0.428 & 0.268 & 0.282 & 0.349 \\
\hline $\mathbf{X 9}$ & 0.216 & 0.378 & 0.797 & 0.571 & 0.509 & 0.728 & 0.352 & 0.624 & 1.000 & 0.685 & 0.564 & 0.480 & 0.458 & 0.249 & 0.300 & 0.313 \\
\hline $\mathbf{X 1 0}$ & 0.242 & 0.303 & 0.523 & 0.729 & 0.550 & 0.485 & 0.458 & 0.631 & 0.685 & 1.000 & 0.531 & 0.491 & 0.497 & 0.285 & 0.308 & 0.322 \\
\hline $\mathbf{X 1 1}$ & 0.207 & 0.332 & 0.369 & 0.719 & 0.495 & 0.505 & 0.280 & 0.460 & 0.564 & 0.531 & 1.000 & 0.489 & 0.477 & 0.256 & 0.263 & 0.300 \\
\hline $\mathbf{X 1 2}$ & 0.273 & 0.343 & 0.859 & 0.361 & 0.509 & 0.438 & 0.320 & 0.389 & 0.480 & 0.491 & 0.489 & 1.000 & 0.468 & 0.285 & 0.306 & 0.335 \\
\hline $\mathbf{X 1 3}$ & 0.294 & 0.394 & 0.691 & 0.649 & 0.429 & 0.323 & 0.449 & 0.428 & 0.458 & 0.497 & 0.477 & 0.468 & 1.000 & 0.316 & 0.282 & 0.272 \\
\hline $\mathbf{X 1 4}$ & 0.270 & 0.412 & 0.242 & 0.496 & 0.324 & 0.308 & 0.302 & 0.268 & 0.249 & 0.285 & 0.256 & 0.285 & 0.316 & 1.000 & 0.597 & 0.469 \\
\hline $\mathbf{X 1 5}$ & 0.348 & 0.414 & 0.571 & 0.767 & 0.305 & 0.315 & 0.348 & 0.282 & 0.300 & 0.308 & 0.263 & 0.306 & 0.282 & 0.597 & 1.000 & 0.505 \\
\hline $\mathbf{X 1 6}$ & 0.331 & 0.405 & 0.596 & 0.346 & 0.410 & 0.408 & 0.212 & 0.349 & 0.313 & 0.322 & 0.300 & 0.335 & 0.272 & 0.469 & 0.505 & 1.000 \\
\hline
\end{tabular}

